\title{
The diagnostic value of FNAB for early diagnosis of thyroid cancer: A Greek center experience
}

Preliminary results

\author{
E. Triantafillou ${ }^{1}$, G. Papadakis ${ }^{1}$, P. Manitarou ${ }^{1}$, E. Panagiotidi ${ }^{1}$, F. Kanouta ${ }^{1}$, A. Drosou ${ }^{1}$, \\ P. Kaldrimidis ${ }^{1}$, V. Kaltzidou ${ }^{1}$, E. Tsouma ${ }^{2}$, A. Alexiadou ${ }^{2}$, S. Plyta ${ }^{2}$, A. Tertipi ${ }^{1}$ \\ ${ }^{1}$ Endocrinological and ${ }^{2}$ Cytology Department. "Metaxa" Anticancer Hospital Greece
}

INTRODUCTION: Fine needle aspiration biopsy (FNAB) is the initial investigation of choice for thyroid nodules. The Bethesda system (B), which classifies thyroid cytological patterns into 6 different categories (B1-6), each linked to a risk of malignancy, has been widely adopted.

METHODS: A total of 563 patients (106 males/457 females), (range $=16-86$ years) underwent FNAB for the same number of thyroid nodules. Their mean age was $56.1 \pm$ 14.1 years. We correlated the demographic profile (age and gender) and sonographic features of these nodules with the FNAB outcome. The Bethesda system for reporting thyroid cytopathology was used.

RESULTS: Out of total 563 cases, 190 (33.7\%) cases were diagnosed as non diagnostic (B1), 339 (60.2\%) were diagnosed as benign (B2), $17(3.0 \%)$ as B3 (atypia/follicular lesion of undetermined significance), 7 (1.2\%) as $\mathrm{B}_{4}$ (follicular neoplasm or suspicious for follicular neoplasm), while $5(0.9 \%)$ cases were categorized as B5 (suspicious for malignancy) and 5 (0.9\%) as B6 (malignant) (Table 1 ). Remarkably, two nodules of category $\mathrm{B}_{5}$ and $\mathrm{B} 6$ each had a maximum diameter of $9 \mathrm{~mm}$ and $8 \mathrm{~mm}$ respectively. When comparing benign result (B2) vs result of category $B_{3}-6$ (Table 2), irregular shape $\left(7.1 \%\right.$ in $\mathrm{B}_{2}$ vs $17.6 \%$ in $\mathrm{B}_{3}-6$, $\left.\mathrm{x}^{2}=4.66, \mathrm{p}=0.043\right)$, ill-defined margins of the nodule $(13.3 \%$ in $B_{2}$ nodules vs $29,4 \%$ in $B_{3}-6$ nodules, $\left.x^{2}=6.4, p=0.020\right)$, and the presence of calcifications $\left(34.2 \%\right.$ in $\mathrm{B}_{2}$ nodules vs $64.7 \%$ in $B 3-6$ nodules, $\left.X^{2}=12.3, P=0.001\right)$ decreased significantly the possibility for benign (B2) result, whereas features such as the size of nodule, the presence of central vascularity, the composition and the hypoechogenity of the nodule did not affect the possibility for $\mathrm{B}_{2}$ vs $\mathrm{B}_{3}-6$ result. Finally, there was no association of gender and age with the Bethesda category result.

CONCLUSION: Our study supports that the irregular shape of a nodule, ill defined margins, and the presence of calcifications decrease the possibility of a Bethesda benign result. FNAB of nodules < $10 \mathrm{~mm}$ may reveal suspicious or positive for malignancy cytology.
Table 1:

FNAB results according to the Bethesda category

\begin{tabular}{l|l} 
FNAB results & $\begin{array}{l}\text { Total } \\
(\mathbf{n}=563)(\%)\end{array}$ \\
\hline BS 1 & $190(33.7 \%)$ \\
BS 2 & $339(60.3 \%)$ \\
BS 3-B6 & $34(6,0 \%)$
\end{tabular}

Table 2:

Demographic and sonographic features according benign (B2) or not (B3-6) cytology

\begin{tabular}{|c|c|c|c|}
\hline $\begin{array}{l}\text { Demographic and } \\
\text { sonographic } \\
\text { features }\end{array}$ & $\begin{array}{l}\text { Bethesda } \\
\text { Category } 2 \\
(n=339) \\
(90.8 \%) \\
\end{array}$ & $\begin{array}{l}\text { Bethesda } \\
\text { Category 3-6 } \\
(n=34) \\
(9.2 \%)\end{array}$ & p-value \\
\hline $\begin{array}{c}\text { Age, mean }(\mathrm{SD}), \\
\text { years }\end{array}$ & $55.88 \pm 14.43$ & $50.54 \pm 15.45$ & NS* \\
\hline Male/female & $68 / 271$ & $7 / 27$ & NS \\
\hline \multicolumn{4}{|c|}{ Shape } \\
\hline Irregular shape & $7.1 \%$ & $17.6 \%$ & 0.043 \\
\hline \multicolumn{4}{|c|}{ Margins } \\
\hline Ill-defined & $13.3 \%$ & $29.4 \%$ & 0.020 \\
\hline \multicolumn{4}{|c|}{ Calcifications } \\
\hline $\begin{array}{l}\text { Calcifications } \\
\text { present }\end{array}$ & $34.2 \%$ & $64.7 \%$ & 0.001 \\
\hline \multicolumn{4}{|c|}{ Size of nodule } \\
\hline Mean \pm S.D $(\mathrm{mm})$ & $15.81 \pm 6.9$ & $16.40 \pm 7.3$ & NS \\
\hline$<10 \mathrm{~mm}$ & $10.0 \%$ & $8.8 \%$ & NS \\
\hline$>10 \mathrm{~mm}$ & $90.8 \%$ & $91.2 \%$ & NS \\
\hline Solitary nodule & $46.0 \%$ & $41.2 \%$ & NS \\
\hline \multicolumn{4}{|c|}{ Composition } \\
\hline Solid nodule only & $48,5 \%$ & $44,1 \%$ & NS \\
\hline \multicolumn{4}{|c|}{ Underlying echogenicity of the parenchyma } \\
\hline Heterogeneity & $79.1 \%$ & $79.4 \%$ & NS \\
\hline \multicolumn{4}{|c|}{ Echogenity of nodule } \\
\hline Hypoechoic & $50.1 \%$ & $61.8 \%$ & NS \\
\hline \multicolumn{4}{|c|}{ Central Vascularity } \\
\hline $\begin{array}{c}\text { Central vascularity } \\
\text { present }\end{array}$ & $19.5 \%$ & $20.6 \%$ & NS \\
\hline $\begin{array}{l}\text { Patients on LT4 } \\
\text { treatment }\end{array}$ & $52.5 \%$ & $50.0 \%$ & NS \\
\hline \multicolumn{4}{|c|}{${ }^{*} \mathrm{NS}=$ Not significant } \\
\hline
\end{tabular}

